\title{
The Dermoid Cyst of the Auricle
}

\author{
Sidika Deniz Yalim ${ }^{1 *}$ and Melike Ordu ${ }^{2}$ \\ ${ }^{1}$ Department of Otorhinolaryngology and Head and Neck Surgery, Adana City Training and Research Hospital, Adana, Turkey \\ ${ }^{2}$ Department of Pathology, Aksaray University School of Medicine, Aksaray, Turkey
}

*Corresponding author: Sidika Deniz Yalim, Department of Otorhinolaryngology and Head and Neck Surgery, Adana City Training and Research Hospital, Adana, Turkey

\begin{abstract}
Dermoid cysts of the auricle are extremely rare. A 13-year-old female patient was admitted to our clinic with the complaint of a painful, slowly growing mass that had been present behind her right ear since birth. Ear examination revealed a soft, approximately $2 \times 2 \mathrm{~cm}$ cystic mass on the posterior aspect of the right auricle. Histopathological examination of the excised mass was reported as dermoid cyst. The patient, who had no problem after the operation, was called to the controls and discharged. We present this case because dermoid cysts of the auricle are extremely rare and should be considered in the differential diagnosis of congenital masses in children.
\end{abstract}

\section{Introduction}

Dermoid cysts are present at birth and predominantly occur in men. They are asymptomatic, slow growing, single cavity cystic masses. Most are in ovaries [1]. Less than $7 \%$ appears in the head and neck region [2].The most common location in the head and neck region is front orbital, in the upper outer part of the orbital. Other settlements are the midline of the nose,the neck, the sublingual region, and the sternal, perineal, scrotal, and sacral regions [3]. Dermoid cysts trapped in the ectoderm sac next to normal folds or surface is a developmental disorder caused by the failure of the ectoderm to leave the neural tube[4].The most valid theory about the dermoid cysts was proposed by New and Erich that was the persistence of the germ layers at birth, along the embryonic fusion line in the deep tissues in the neck. The irregular growth and differentiation of these cells causes the appearance of dermoid cysts. Dermoid cysts are divided into 3 histological types: epidermoid, dermoid and teratoma. Epidermoid cysts contain laminated keratin materials and does not contain a sebaceous gland around. Dermoid cysts are surrounded with a stratified squamous cell epithelium and they are subcutaneous tumors, and they contain various types of skin supplements such as hair follicle, sebaceous gland and sweat glands. Teratomas originate from totipotent cells, contain all three embryonic germ layers and are true neoplasms [4].

\section{Case Report}

Thirteen-year-old female patient with a mass complaint in the right auricle admitted to the Otorhinolaryngology outpatient clinic of Kadirli State Hospital. The patient's mother told that the mass existed since the birth of the child. She stated that the mass was small and painless at the beginning. For the past few years, the mass was growing and became painful. In the otorhinolaryngologic examination of the patient, there was a soft, painless, cystic mass in the posterior part of the upper inner quadrant of the right auricle just lateral to the sulcus. The mass was about $2 \times 2 \mathrm{~cm}$ in size. The mass is totally excised under local anesthesia. In the macroscopic examination of specimen, the cyst was surrounded by a stratified squamous cell epithelium and the hair follicles were seen in the lumen. In the $4 \times 10$ microscopic examination with hematoxylin-eosinophil stain the cyst was surrounded by the stratified squamous cell epithelium and sebaceous glands were present in the dermis and hair follicle structures were seen in the cyst lumen. Histopathological examination results were reported as dermoid cyst.

\section{Discussion}

When we look at the literature, dermoid cysts of the auricle are extremely rare. Ikeda reported 2 cases of the dermoid cyst of 
the auricle.1 Later, Samper, Bauer, Meagher and DeSouza reported cases of postauricular dermoid cyst[4-7].In 2014, Horikiri et al. reported dermoid cyst of the auricle [8]. Jung et al. reported a case of the congenital dermoid cyst in the right auriculocephalic sulcus[9]. Byeon et al. reported a dermoid cyst on the posterior of the auricle[10]. Also,Wisevarver et al. reported a case of a dermoid cyst on the posterior of the right auricle [11]Nasirmohtaram et al. reported a case of a dermoid cyst located in the concha [12]. Kim et al. reported a case of acquired dermoid cyst and stated that it is not different from the congenital dermoid cyst. Congenital dermoid cyst is surrounded by normal tissues the acquired dermoid cyst is surrounded by fibrous scar tissue[13]. The differential diagnosis of the post auricular cyst includes the epidermal inclusion cyst, the trichilemmal cyst, the lipoma, and the hemangiomas. The trichilemmal or the sebaceous cysts are clinically similar to the epidermoid cysts. The diagnosis was confirmed histologically by the presence of the amorphous keratin material in the cyst cavity. The lipomas are common benign soft tissue adipose tumors and are similar to the dermoid cysts. Hemangiomas are present at birth and are benign tumors of the vascular endothelium and spontaneous involution is possible[8]. The treatment of the dermoid cyst is removal of the cyst wall with complete surgical excision. If it is not removed, it may result in relapse or infection[10].The treatment prevents the conversion to malignancy.

As a result, the dermoid cysts are rare, usually benign, and very rarely malignant. They are congenital masses that can show transformation and can be seen in many parts of the body. They must be considered in the differential diagnosis of congenital ear masses, especially in the children.

\section{References}

1. Ikeda M, Muto J, Omachi S (1990) Dermoid cyst of the auricle: report of two cases. Auris Nasus Larynx 16(4): 193-197.

2. Reddy VS, Radhakrishna K, Rao PL (1991) Lingual dermoid. J Pediatr Surg 26(12): 1389-1390.

3. Batsakis JG (1979) Tumors of the head and neck: Clinical and pathological considerations. $2^{\text {nd }}$ Ed. Baltimore Williams\&Wilkins, USA p. 226-232.

4. Samper A (2000) Dermoid cyst on the auriculotemporal area. Plast Reconstr Surg 106(4): 947-948.

5. Bauer DJ, Diwan R, Honig BK, Yokel B (1994) Large aymptomatic mass on the ear: dermoid cyst of the auricle. Arch Dermatol 130(7): 913-917.

6. Meagher PJ, Morrison WA (2001) An unusual presentation of bilateral prominent ears. Br J Plast Surg 54(4): 366-367.

7. DeSouza BA, Dey C, Carver N (2003) A rare case of dermoid cyst behind the ear. Plast and Reconstr Surg 112(7): 1972.

8. Horikiri M, Ueda K, Kato M (2014) Dermoid cyst of the auricle: A rare manifestation. BMJ Case Rep 17: 2014.

9. Jung KH, Choi HJ, Nam DH (2014) Caracteristics of the dermoid cyst of the auricule. Arch Craniofac Surg 15(1): 22-27.

10. Byeon JY, Choi HJ, Lee JH (2018) Rare Report of Unilateral Postauricular Dermoid Cyst. J Craniofac Surg 29(3): 767-768.

11. Wisecarver IR, Cusimano LA, Mundinger GS (2017) Posterior auricular mass. Eplasty 22:17:ic16.

12. Nasirmohtaram S, Akbari M (2016) Dermoid cyst within concha: a case report. Acta Med 89 Iran 54(6): 407-408.

13. Kim HJ, Burm JS, Pyon JK, Kim YW (2007) Acquired dermoid cysts within 91 subcutaneous scar tissue. J Korean Soc Plast Reconstr Surg 34: 507510.

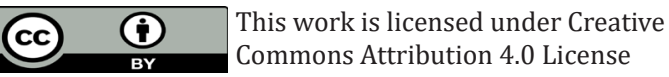

To Submit Your Article Click Here: Submit Article

DOI: $10.32474 /$ SJ0.2020.04.000200

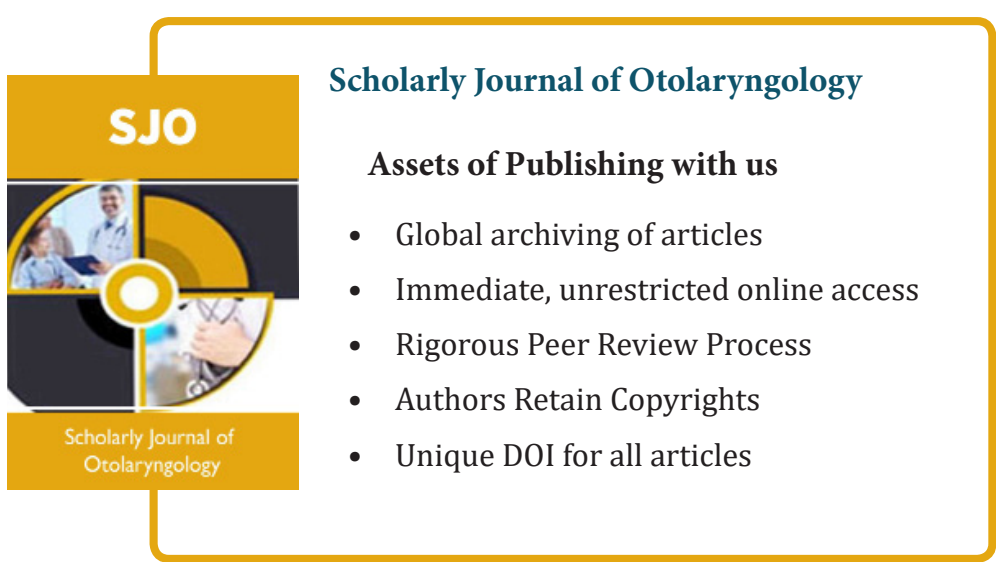

